\title{
Biostratigraphy and paleoecology of an unusual palynological record from the Aquidauana Formation, Late Pennsylvanian of Paraná Basin
}

\author{
PAULO A. SOUZA ${ }^{1}$, JOSÉ A.J. PERINOTTO ${ }^{2}$, CRISTINA M. FÉLIX ${ }^{1}$ and BRUNO C. ARAÚJO ${ }^{2}$ \\ ${ }^{1}$ Programa de Pós-Graduação em Geociências, Laboratório de Palinologia Marleni Marques-Toigo, Instituto de Geociências, \\ Universidade Federal do Rio Grande do Sul, Av. Bento Gonçalves, 9500, 91540-000 Porto Alegre, RS, Brasil \\ ${ }^{2}$ Programa de Pós-Graduação em Geociências e Meio Ambiente, Departamento de Geologia Aplicada, Instituto de \\ Geociências e Ciências Exatas, Universidade Estadual Paulista, Av. 24-A, 1515, 13506-900 Rio Claro, SP, Brasil
}

Manuscript received on August 21, 2014; accepted for publication on October 24, 2014

\begin{abstract}
The Aquidauana Formation is a Permo-Carboniferous sedimentary unit, widely stratigraphicaly distributed in the northwestern and northern portions of the Paraná Basin. However, little paleontological data is available from this formation, preventing accurate biostratigraphic and paleoecological interpretations. An abundant, diversified and well preserved assemblage of palynomorphs was recognized from sampling conducted in an outcrop section in Cipolândia District of Aquidauana Municipality, state of Mato Grosso do Sul, Brazil. A total of 35 indigenous palynomorph taxa was recognized, comprising 6 species of spores (related to 5 genera), 28 species of pollen grains (14 genera) and 1 species of chlorophycean algae. Monosaccate pollen grains are exceptionally dominant, representing $90.38 \%$ of the association, particularly constituted by species of the genera Cannanoropollis (30.41\% of the total assemblage), Potonieisporites (28.14\%) and Plicatipollenites (19.52\%). This quantitative overrepresentation is not usual from Gondwana deposits, revealing a particular plant dominance of Cordaitales in the terrestrial flora. These results are interpreted as an upland ecology characterized by plants with a moisture-independent reproduction strategy, under a glacial climate influence. Certain species of pollen allow assignment of this assemblage to the Crucisaccites monoletus Zone (Late Pennsylvanian), which had been recognized only in the middle portion of the Itararé Group at the northeastern margin of the basin.
\end{abstract}

Key words: biostratigraphy, paleoecology, palynology, Pennsylvanian.

\section{INTRODUCTION}

The northwestern margin of the Paraná Basin exhibits a thick section of sedimentary outcrops, related to the Furnas, Ponta Grossa (both of Devonian age) and the Aquidauana (Permo-Carboniferous) formations. The Aquidauana Formation is mainly composed of sandstones and diamictites, and it is laterally

Correspondence to: Paulo Alves de Souza

E-mail: paulo.alves.souza@ufrgs.br correlated with the Itararé Group (França and Potter 1988, Milani et al. 2007). This unit, as well as the Itararé Group and correlated units in South America and Africa are representatives of the Upper Paleozoic glacial event in the Western Gondwana. Fossils of different nature are well known from these glaciogenic units, such as those from the Itararé Group, comprising plant remains, palynomorphs, vertebrates and invertebrates, allowing significant 
biostratigraphic and paleoecological contributions (see summary in Holz et al. 2010). However, paleontological records from the Aquidauana Formation are very scarce and when present, they describe sporadic isolated few fossil specimens.

The fossil content of the Aquidauana Formation in the state of Mato Grosso do Sul comprises one record of an ichnofossil (invertebrate traces), records of fish scales (Paleoniscids), one fragment of insect wing, indeterminate plant remains (see synthesis in Scheffler et al. 2010), and limited palynomorphs (Daemon and Quadros 1970). These scarce, low variety and sparse occurrences prevent adequate age attributions as well as limiting paleoenvironmental reconstructions.

Palynomorphs listed from the Aquidauana Formation concern few specimens of pollen grains, some of them with open nomenclature (Daemon and Quadros 1970). This palynological content is relatively poor when compared with associations derived from the northeastern and south portions of the basin, preventing accurate correlations.

Efforts have been made recently, attempting new palynological studies from outcrop samples of the Aquidauana Formation. However, samples are generally barren of palynomorphs, with only semidestroyed phytoclasts and amorphous organic matter recorded. These limitations are attributed to the lithological nature of the outcrops, with sediments primarily comprised of red to yellow sandstones and diamictites with high degree of weathering, indicating deposition in oxidizing conditions (see Milani et al. 2007), where palynomorphs are generally destroyed by oxidation.

This paper presents new palynological records from the Aquidauana Formation derived from an outcrop section located at Cipolândia, state of Mato Grosso do Sul, Brazil, from an expressive and unusual layer of shale, once this lithology is rare or absent in the Aquidauana Formation. These data were preliminarily presented by Souza et al. (2013), who registered several species of spores and pollen grains, which amplify the paleontological content to this unit, with biostratigraphical and paleoenvironmental significance.

\section{MATERIALS AND METHODS}

The outcrop section studied comprises ca. $50 \mathrm{~m}$ of sediment, exposed on the state road MS-447, approximately $12 \mathrm{~km}$ from the east/northeast of the Cipolândia District, in the municipality of Aquidauana, state of Mato Grosso do Sul (Fig. 1). The sampled section (Fig. 2a) is comprised, in ascending stratigraphic order, of a massive diamictite (Fig. 2b), with faceted and striated polymitic pebbles, cobbles and boulders, of variable dimensions (decametric to metric), chaotically distributed within a siltysandy matrix. This diamictite is stratigraphicaly followed by a sandstone package (Fig. 2c and d), of varied granulometry, exhibiting planar and trough cross-stratification (in sets sometimes separated by marked surfaces of pebbles and cobbles), with rare matrix and dispersed pebbles. A thin layer of dark grey to greenish shale occurs in the upper portion of the section (Fig. 2e), with varying degrees of weathering, and rare dropstones.

Three samples (AQ-84, 86 and 87, see figs. 1c and $2 \mathrm{a}$ ) were processed according to the standard palynological technique for Paleozoic materials (Quadros and Melo 1987), which comprises the removal of carbonates and silicates by using hydrochloric and hydrofluoric acids. Palynomorphs within the 10-250 $\mu \mathrm{m}$ size range were concentrated in the final organic residues, from which glass slides were mounted with polyester resins. Taxonomic identifications and photomicrographs were made under a standard optical microscope. The slides are housed at the Paleontological Museum of the Rio Grande do Sul Federal University (UFRGS), under codes MP-P (AQ-84: MP-P 8920, 10259; AQ-86: 8921; AQ-87: 8919, 10257, 10258). All palynomorphs recorded from the AQ-87 outcrop (geographic coordinates 678,346 E and 7,773,846 $\mathrm{N})$ were considered in the quantitative analysis, 


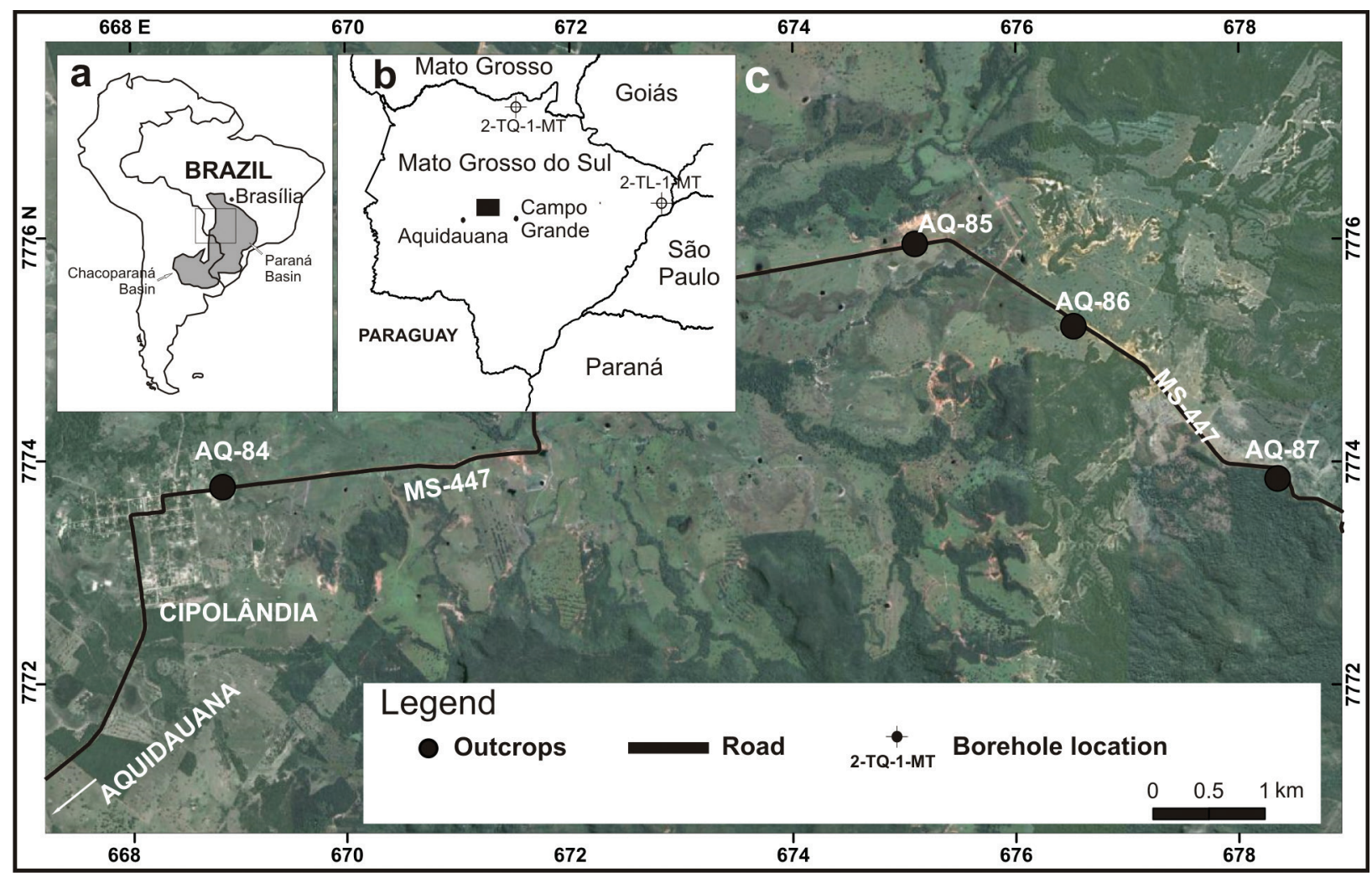

Figure 1 - Location of study area. (a) Paraná and Chacoparaná Basins in South America, with indication of area in b; (b) Location of area and boreholes previously study by Daemon and Quadros (1970) in the state of Mato Grosso do Sul, Brazil; (c) Outcrops studied nearby Cipolândia, based on Google Earth Image.

totalizing 707 taxa considered indigenous and another 17 reworked from older strata.

\section{RESULTS}

Among the three processed samples, only which derived from the AQ-87 outcrop revealed a significant palynological assemblage, with potential for biostratigraphical and paleoecological interpretations. The other samples presented limited palynomorphs, with poor preservation, dominated by degraded phytoclasts and amorphous organic matter.

The AQ-87 assemblage is composed of diverse, well preserved and abundant palynomorphs, comprising 35 species of indigenous taxa, related to 6 species of spores (related to 5 genera), 28 species of pollen grains (14 genera) and 1 species of chlorophycean algae, as listed in table I.
Furthermore, reworked species of spores, acritarchs and prasinophycean algae were also registered. Photomicrographs of selected species are presented in figures 3 and 4.

Palynomorphs from AQ-87 outcrop are very well preserved, rarely showing fragmentation or corrosion. Phytoclasts are subordinate, comprising opaque and non-opaque (brown to dark yellow) types, including fragments of cuticles and tracheids, generally with angular sides, elongated to equidimensional in shape. Interestingly and exceptionally, three specimens of indigenous pollen grains, present evidence of shearing, containing breaking but with no complete fragmentation of the grain. This is a type of taphonomic damage compared to those in Devonian palynomorphs described by Arai and Melo (2003). 


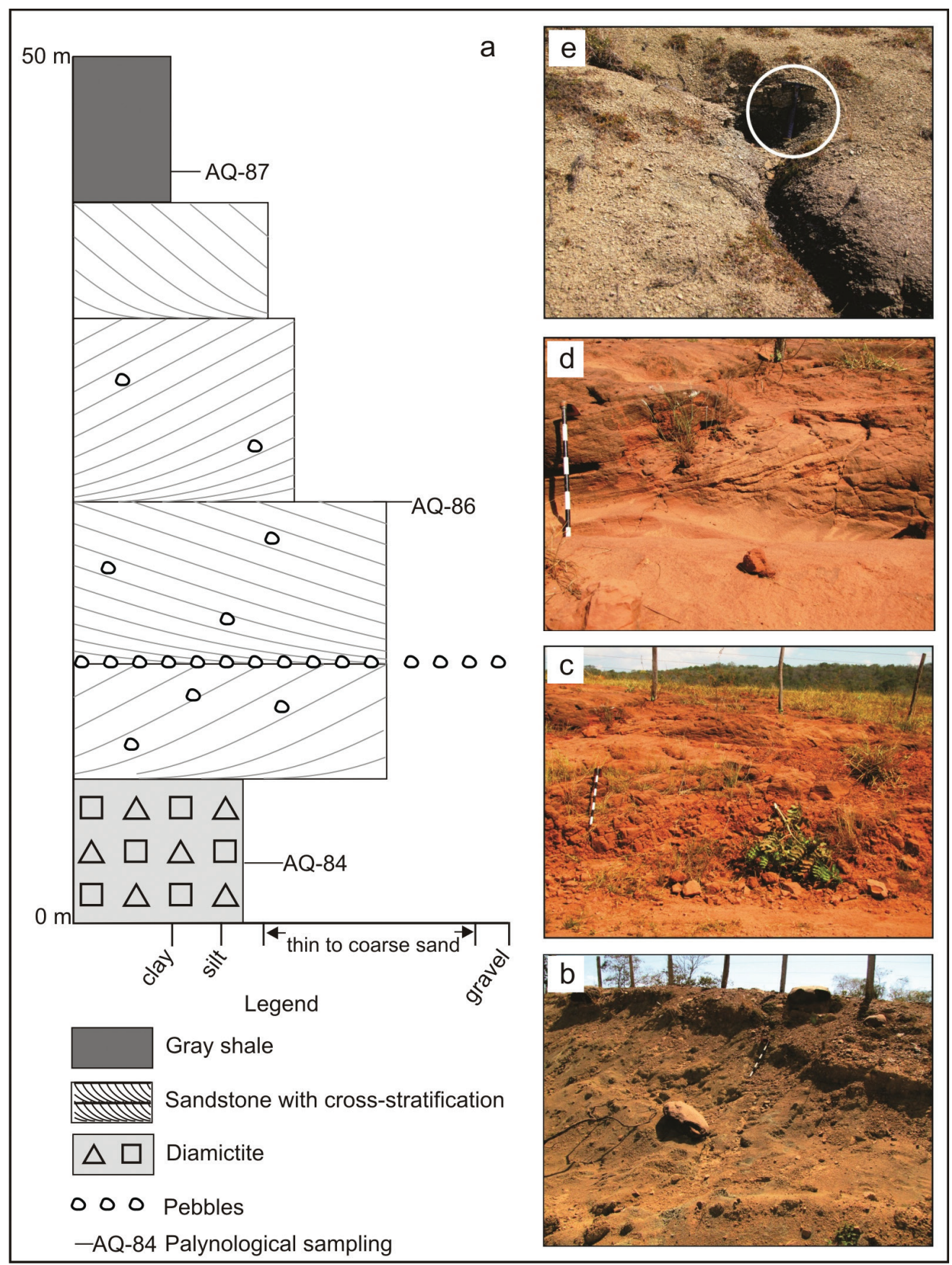

Figure 2 - Outcrops and general stratigraphy. (a) Columnar section of the outcrops sampled along the Road MS-447; (b) AQ-84: diamictites with submetric clasts; (c and d) AQ-86: medium to thick sandstones, with dispersed clasts and planar/trough cross-stratification; (e) AQ-87: grey shale. Scale in b, $\mathrm{c}$ and $\mathrm{d}$ has spacing intervals of $10 \mathrm{~cm}$; hammer as scale in a.

In terms of quantitative analysis, 707 specimens are considered coeval to the sediments (see Table II). In order of dominance, monosaccate pollen grains represent $90.38 \%$ (mainly species of the genera Cannanoropollis, Potonieisporites and Plicatipollenites), spores $5.66 \%$, bisaccate pollen grains $2.26 \%$ and chlorophycea algae (Botryococcus braunii) $1.70 \%$. 
TABLE I

List of palynomorphs recorded in this paper from the Aquidauana Formation and respective illustrations in Figures 3 and 4.

\begin{tabular}{|c|c|}
\hline Spores & Fig. \\
\hline Calamospora sp. & 3.a \\
\hline Punctatisporites gretensis (Hart) Balme and Hennelly 1956 & 3.b \\
\hline Convolutispora sp. & 3.c \\
\hline Cristatisporites inconstans Archangelsky and Gamerro 1979 & 3.d \\
\hline \multicolumn{2}{|l|}{ Lundbladispora riobonitensis Marques-Toigo and Picarelli 1984} \\
\hline \multicolumn{2}{|l|}{ L. braziliensis (Pant and Srivastava) Marques-Toigo and Pons emend. Marques-Toigo and Picarelli 1984} \\
\hline \multicolumn{2}{|l|}{ Pollen grains } \\
\hline Florinites occultus Habib 1966 & 3.1 \\
\hline Costatascyclus crenatus Felix and Burbridge 1967 & 4.f \\
\hline Cannanoropollis janakii Potonié and Sah 1960 & 3.e \\
\hline Cannanoropollis densus (Lele) Bose and Maheshwari 1968 & 3.9 \\
\hline Cannanoropollis triangularis (Mehta) Bose and Maheshwari 1968 & 3.f \\
\hline \multicolumn{2}{|l|}{ Cannanoropollis mehtae (Lele) Bose and Maheshwari 1968} \\
\hline Plicatipollenites malabarensis (Potonié and Sah) Foster 1975 & 3.h \\
\hline Plicatipollenites densus Srivastava 1970 & $3 . \mathrm{i}$ \\
\hline \multicolumn{2}{|l|}{ Plicatipollenites trigonalis Lele 1964} \\
\hline \multicolumn{2}{|l|}{ Circumplicatipollis plicatus Ottone and Azcuy 1988} \\
\hline Divarisaccus stringoplicatus Ottone 1991 & $3 . \mathrm{k}$ \\
\hline \multicolumn{2}{|l|}{ Crucisaccites latisulcatus Lele and Maithy 1964} \\
\hline Crucisaccites monoletus Maithy 1965 & 3.j \\
\hline \multicolumn{2}{|l|}{ Stellapollenites talchirensis Lele 1965} \\
\hline Caheniasaccites flavatus Bose and Kar emend. Azcuy and Di Pasquo 2000 & 4.9 \\
\hline \multicolumn{2}{|l|}{ Caheniasaccites verrucosus (González-Amicón) Gutiérrez 1993} \\
\hline Potonieisporites novicus Bhardwaj emend. Poort and Veld 1997 & 4.a \\
\hline \multicolumn{2}{|l|}{ Potonieisporites neglectus Potonié and Lele 1961} \\
\hline Potonieisporites barrelis Tiwari 1965 & 4.b \\
\hline Potonieisporites densus Maheshwari 1967 & 4.e \\
\hline Potonieisporites congoensis Bose and Maheshwari 1968 & 4.d \\
\hline Potonieisporites magnus Lele and Karim 1971 & 3.m \\
\hline Potonieisporites triangulatus Tiwari 1965 & $4 . \mathrm{i}$ \\
\hline Potonieisporites lelei Maheshwari 1967 & 4.c \\
\hline \multicolumn{2}{|l|}{ Gondwanapollis sp. } \\
\hline Meristocorpus explicatus Playford and Dino 2000 & 4.h \\
\hline Scheuringipollenites maximus (Hart) Tiwari 1973 & $4 . j$ \\
\hline \multicolumn{2}{|l|}{ Limitisporites rectus Leschik 1956} \\
\hline \multicolumn{2}{|l|}{ Chlorophyceae algae } \\
\hline Botryococcus braunii Kützing 1849 & $4 . \mathrm{k}$ \\
\hline
\end{tabular}

Reworked taxa are represented by 17 specimens, corresponding to Prasinophycean algae (Maranhites spp., Tasmanites spp., Navifusa bacilla), acritarchs (Gorgonisphaeridium spp.) and spores (Grandispora spp., Emphanisporites rotatus, Geminospora lemurata and Retusotriletes crassus). In comparison with the coeval palynomorphs, no difference was observed in their preservation (color or fragmentation degree).

\section{DISCUSSION}

BIOSTRATIGRAPHY

The palynostratigraphic proposal of Daemon and Quadros (1970) is the only available zonation that encompasses the Aquidauana Formation in the north and northwestern portion of the basin (Fig. 5). According to those authors, the G, H and I intervals 
TABLE II

Absolute amount and relative frequency of palynomorphs.

\begin{tabular}{|c|c|c|}
\hline $\begin{array}{l}\text { Group of coeval } \\
\text { palynomorphs }\end{array}$ & $\begin{array}{l}\text { Absolute } \\
\text { amount }\end{array}$ & $\%$ \\
\hline Spores & 40 & 5.66 \\
\hline Monosaccate pollen grains & 639 & 90.38 \\
\hline Caheniasaccites & 29 & 4.10 \\
\hline Cannanoropollis & 215 & 30.41 \\
\hline Circumplicatipollis & 3 & 0.42 \\
\hline Costatascyclus & 3 & 0.42 \\
\hline Crucisaccites & 12 & 1.70 \\
\hline Divarisaccus & 34 & 4.81 \\
\hline Florinites & 2 & 0.28 \\
\hline Plicatipollenites & 138 & 19.52 \\
\hline Potonieisporites & 199 & 28.14 \\
\hline Meristocorpus & 2 & 0.28 \\
\hline Stellapollenites & 2 & 0.28 \\
\hline Bisaccate pollen grains & 16 & 2.26 \\
\hline Gondwanapollis & 1 & 0.14 \\
\hline Limitisporites & 2 & 0.28 \\
\hline Scheuringipollenites & 13 & 1.84 \\
\hline Chlorophyceae algae & 12 & 1.70 \\
\hline Total & 707 & 100.00 \\
\hline
\end{tabular}

were recognized from the Aquidauana Formation. These intervals were mainly recorded from core samples of the 2-TL-1-MT borehole (Três Lagoas). Palynomorphs were also recorded by those authors from the 2-TQ-1-MT boherole (Taquari) and the A284 outcrop ("Colônia Merure"), but assemblages are scarcer and lack diversity and are less accurate for biostratigraphy. The approximate location of these last boreholes is indicated in Fig. 1b; location of the A284 outcrop is not available from the original paper of Daemon and Quadros (1970).

Taking into account the assemblage recorded here, a general correlation could be made with the subsurface cores T19 to T21 of the 2-TL-1MT, where the intervals $\mathrm{G}-\mathrm{H}_{3}$ were recognized. A correlation with a younger interval is unable due the presence of Stellapollenites talchirensis (originally designated as "P393" by Daemon and Quadros 1970) and Protohaploxypinus goraiensis (designated as Protohaplypinus sp. "P391") from the samples of this borehole. Both species are absent in the
AQ-87 assemblage and they are, according to new palynostratigraphic interpretations presented here, guide species for higher stratigraphic levels within the correlated Itararé Group, as discussed below.

According to Souza and Marques-Toigo (2005) and Souza (2006), four interval zones based on spore-pollen taxa are distributed through the Gondwana I Supersequence of the Paraná Basin (see Fig. 5): Ahrensisporites cristatus (AcZ), Crucisaccites monoletus (CmZ), Vittatina costabilis (VcZ) and Lueckisporites virkkiae (LvZ). The AcZ and $\mathrm{CmZ}$ are Pennsylvanian in age (equivalent to the $\mathrm{G}_{-} \mathrm{H}_{2}$ intervals of Daemon and Quadros 1970), whilst VcZ and $\mathrm{LvZ}$ (equivalent to the $\mathrm{H}_{3}-\mathrm{L}_{3}$ intervals) are Cisuralian to early Guadalupian in age (Early to Middle Permian), according to Holz et al. (2010) and Mori et al. (2011). The Pennsylvanian zones of Souza (2006) are yet to be found outside the area where they were erected, stratigraphically corresponding to the basal to middle deposits of the Itararé Group, in the states of São Paulo and Paraná.

In general, both $\mathrm{AcZ}$ and $\mathrm{CmZ}$ as well as the intervals $\mathrm{G}-\mathrm{H}_{3}$ present palynological assemblages dominated by spores and monosaccate pollen grains. Among the latter, radiometric and bilateral taxa are more common, mainly represented by species of Plicatipollenites, Cannanoropollis and Potonieisporites, as verified in the AQ-87 assemblage of the Aquidauana Formation.

Certain guide palynomorph from the zonation of Souza (2006) were recorded from the AQ-87 sample assemblage, allowing biostratigraphic calibration. Among them, Crucisaccites monoletus and Scheuringipollenites maximus are the only pollen species stratigraphically restricted to the $\mathrm{CmZ}$, confirming this biozone attribution. This biostratigraphic assignment represents a more detailed refinement in comparison to the intervals of Daemon and Quadros (1970), whereby the association of the AQ-87 would correspond to the G-H intervals, with ages between the Late Pennsylvanian to the Early Permian. 


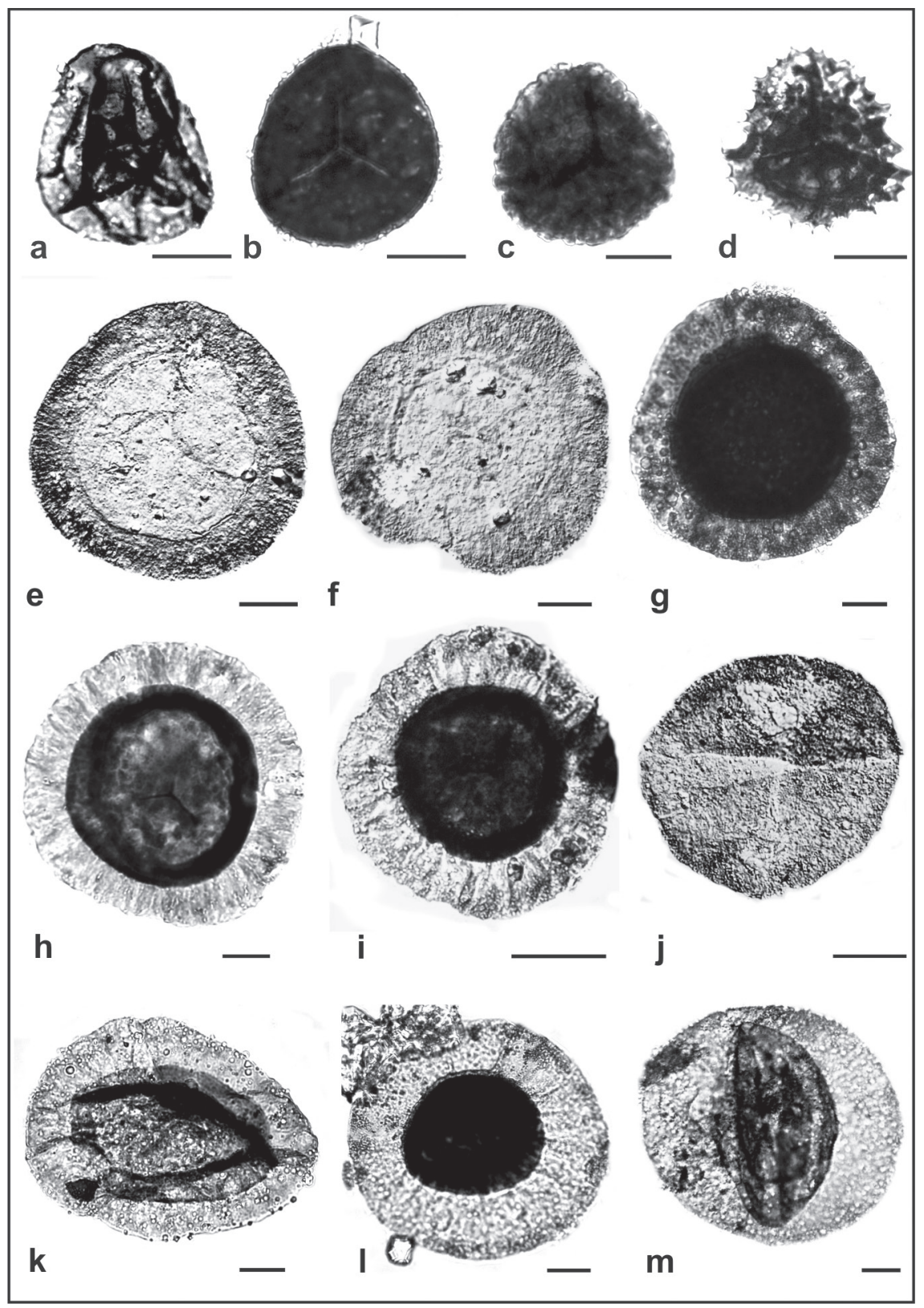

Figure 3 - Photomicrographs of selected palynomorphs. (a) Calamospora sp., slide MP-P 8919, England Finder coordinate J37-2, (b) Punctatisporites gretensis, 10257, V36; (c) Convolutispora sp., 10257, L47; (d) Cristatisporites inconstans, 10258, N48; (e) Cannanoropollis janakii, 10257, U44; (f) Cannanoropollis triangularis, 10257, T432; (g) Cannanoropollis densus, 10257, R31-4; (h) Plicatipollenites malabarensis, 8919 W60; (i) Plicatipollenites densus, 8919, Q43; (j) Crucisaccites monoletus, 8919, V36-2; (k) Divarisaccus stringoplicatus, 8919, S32; (I) Florinites occultus, 10258, O41-3; (m) Potonieisporites magnus, 8919, V47. Scale bar corresponds to $20 \mu \mathrm{m}$.

Besides palynomorph taxa considered coeval, species of spores (Retusotriletes crassus, Geminospora lemurata, Emphanisporites rotatus,
Grandispora spp.), acritarch and prasinophycean algae (Navifusa bacilla, Maranhites spp., Tasmanites spp., and Gorgonisphaeridium spp.) from older strata 


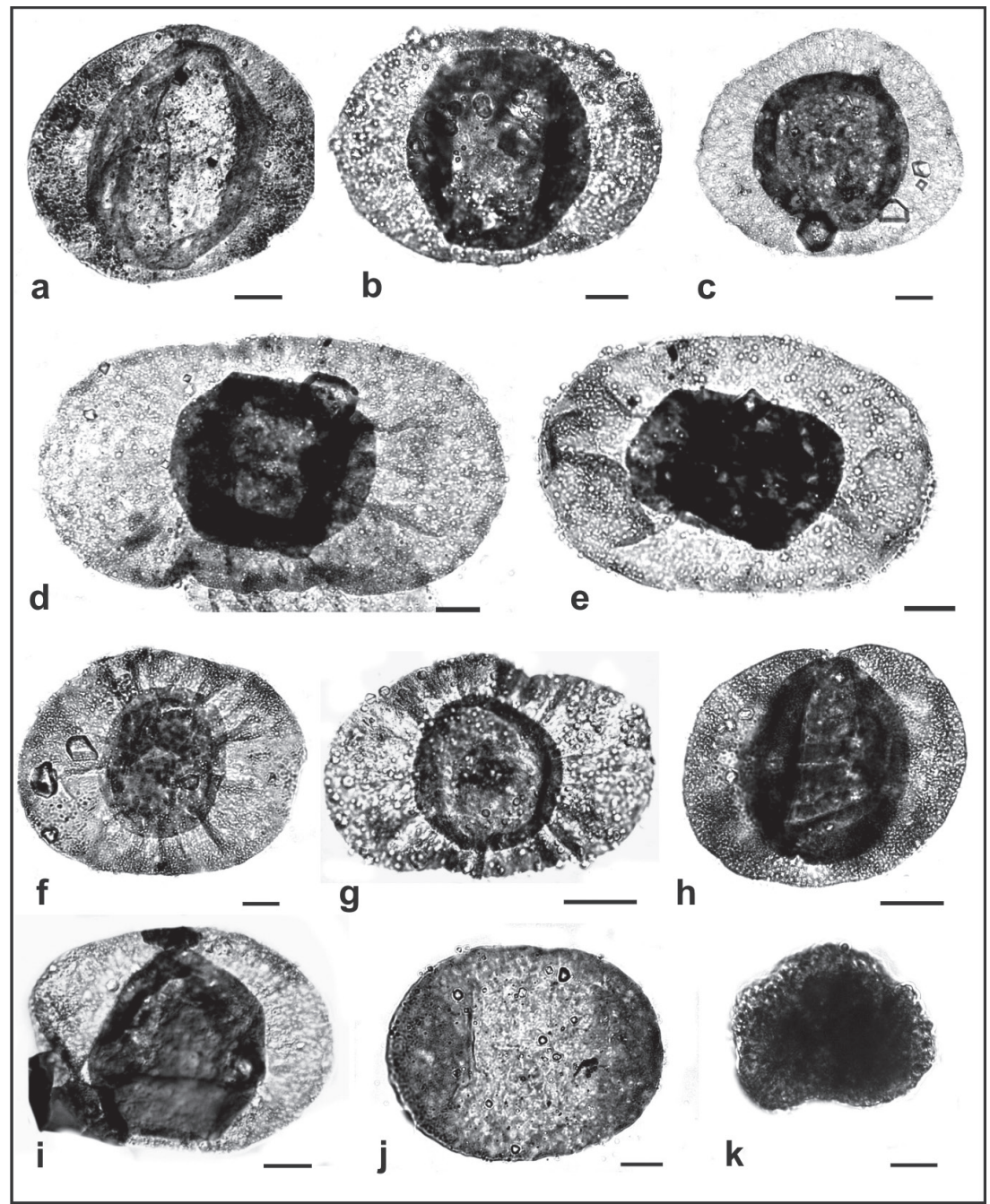

Figure 4 - Photomicrographs of selected palynomorphs. (a) Potonieisporites novicus, slide MP-P 10257, England Finder coordinate T38; (b) Potonieisporites barrelis, 8919, E53; (c) Potonieisporites lelei, 8919, W52; (d) Potonieisporites congoensis, 10257, W48-4; (e) Potonieisporites densus, 8919, V54; (f) Costatascyclus crenatus, 10257, F42; (g) Caheniasaccites flavatus, 8919, B53-4; (h) Meristocorpus explicatus, 8919, U52-2; (i) Potonieisporites triangulatus, 8919, K41-2; (j) Scheuringipollenites maximus, 10257, U42; (k) Botryococcus braunii, 10257, M40. Scale bar corresponds to $20 \mu \mathrm{m}$.

were found, interpreted as reworked (17 specimens in total). For the most part, these specimens are well preserved with no evidence of damage during reworking, such as color differentiation or fragmentation. These features are very common from the basal and middle portions of the Itarare Group (see Souza and Petri 1998, Souza 2006), where AcZ and $\mathrm{CmZ}$ are present.

\section{PALEOECOLOGY AND PALAEOENVIRONMENT}

Spores and monosaccate pollen grains are dominant within the palynological assemblages from Pennsylvanian to early Permian Gondwanan deposits. This pattern of representation is interpreted as a general tendency for spore-pollen distribution across Gondwana (Venkatachala et al. 1995, Felix et al. 2007, Stephenson 2008). However, dominance 


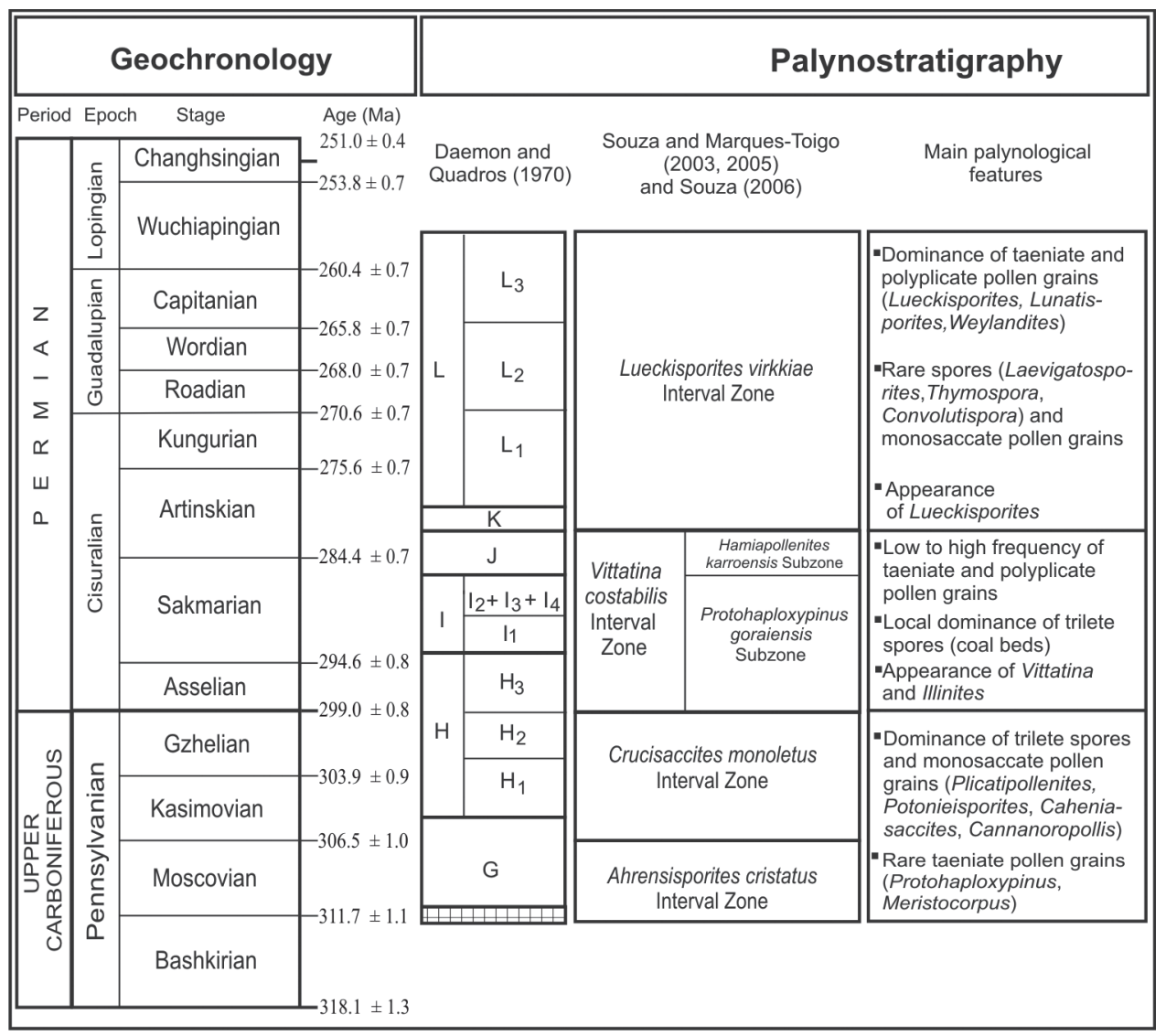

Figure 5 - Correlation of main Pennsylvanian/Permian palynozones proposed for the Brazilian part of the Paraná Basin and their most important characteristics (modified from Souza 2006).

of monosaccate pollen over spores are not rare, with several occurrences in distinct parts of Gondwana, most part concerning to glacial deposits, such as in South America (Azcuy 1979, Playford and Dino 2000), India (Tiwari and Tripath 1992, Srivastava and Agnihotri 2009), Antarctica (Lindström 1995) and Australia (Balme 1980, Backhouse 1991, Jones and Truswell 1992). In these cases, radiosymetric and bilateral monosaccate pollen mostly belonging to the genera Cannanoropollis, Plicatipollenites and Potonieisporites are well represented in terms of abundance and/or diversity.

In the Brazilian area of the Paraná Basin, dominance of monosaccate pollen grains over spores was presented from distinct deposits of the glaciogenic Itararé Group, in different stratigraphical levels, concerning its basal (Souza et al. 2003), middle
(Di Pasquo et al. 2003) and upper (Gandini et al. 2007) portions. Although absolute frequencies were not always stated by those authors, none of these records from the Paraná Basin exhibit such dominance by this group of pollen grains, as observed herein.

Pollen related to Plicatipollenites, Cannanoropollis and Potonieisporites were derived from a primitive, monosaccate-producing gimnosperm (Balme 1995), related to Late Paleozoic arboreal plants (probably Cordaitales) characterized by a moisture-independent reproduction strategy, representing an upland flora (Stephenson and Osterloff 2002). Cordaitales are an extinct group of Gymnosperm, of widespread distribution within Pennsylvanian to Permian deposits, variable in habit (mainly arboreal) and ecological requirements. These plant remains have also been reported from 
deposits of poorly drained soils (Wagner 2001). Although macrofloristic remains of this taxon are more frequent in swamp environments, as a coalforming component, palynological associations are generally dominated by spore-producing taxon, mainly lycopsids and subordinately sphenopsids and filicopsids as demonstrated by Cazzulo-Klepzig et al. (2005) and Boardman et al. (2012) from Permian coals of the Paraná Basin.

Thus the higher frequency of these monosaccate three genera in the AQ-87 Aquidauana association is unusual in palynological records from Pennsylvanian to Permian Gondwana strata. This evidence can be explained, according to Stephenson and Osterloff (2002), by a monosaccate-producing upland ecology and a lowland fern ecology in Gondwana, being influenced by a cold climate during the PermoCarboniferous. According to those authors, the monosaccate-producing flora was present in upland areas during occupation of floodplains by the cold climate fern community; lacustrine flooding resulting from minor deglaciation events could prevent the persistence of lowland spore-producing plants and, consequently, the increase in representation of the upland flora. Spores and bisaccate pollen grains are very scarce, both representing less than $8 \%$ of the total assemblage (see table II). Bisaccate pollen grains are more abundant in Gondwana basins from deposits overlying glaciogenic units, as a result of climate amelioration, representing a changeover of the upland ecology.

This scenario is also supported by the lithofaciological analysis. The section is interpreted as representing a fining upward cycle, as result of a decrease energy, characterizing an event in the front of glacial retreat and subsequent flooding. Although rare, dispersed dropstones within the shale, indicates glacial influence. The continental nature of the sedimentation is confirmed by the presence of Botryococcus, a chlorophycean algae typical of freshwater (Batten and Grenfell 1996). No marine sedimentary or palynological evidence was recorded.

\section{CONCLUSIONS}

This paper examines a well preserved assemblage of palynomorph, comprised by taxa of spores, pollen grains and chlorophycean algae which contribute new ideas concerning the relative age and paleoecology of the Aquidauana Formation, northwestern Paraná Basin. Predominance of oxidized sandstones, conglomerates and diamictites harms preservation of palynomorphs, which become very rare in the Aquidauana Formation; here we sampled a productive shale layer, which is an uncommon lithology in this unit.

The presence of Crucisaccites monoletus and Scheuringipollenites maximus allowed correlation with the Crucisaccites monoletus interval Zone $(\mathrm{CmZ})$ previously established in the northeastern area of the basin. It implies a late Late Pennsylvanian age and a biostratigraphical correlation of the studied section of the Aquidauana Formation with the middle portion of the Itarare Group, both glaciogenic in origin. It is the first recognition of this Pennsylvanian interval zone outside the area it was erected (states of São Paulo and Paraná), demonstrating a wider area of continuous deposition. However, the age span of Aquidauana Formation reaches the Early Permian, when taking into account previous subsurface data with typical guide species of the Vittatina costabilis Zone.

An unusually dominant monosaccate pollen grain representation $(90.38 \%)$ was recorded from the Aquidauana association, particularly Cordaitales pollen types, such as Cannanoropollis, Plicatipollenites and Potonieisporites, which represent up to ca. $78 \%$ of the total assemblage. Considering other similar records throughout Gondwanan basins, a relationship with glaciogenic deposits of Late Pennsylvanian and Early Permian ages is inferred. The paleoecological significance of these data suggests predominance of an upland ecology characterized by plants with a moistureindependent reproduction strategy. A continental 
interpretation is indicated by palynological and sedimentological evidence, characterizing deposition in the front of retreating glacier, with consequent flooding of the lowland areas. Palynological association is derived almost exclusively from upland surrounding areas, where a Cordaitales flora was dominant.

\section{ACKNOWLEDGMENTS}

Authors would like to thank to Adam D. McArthur for helping with the English language revision and additional contributions. This work was supported by research grants awarded by Conselho Nacional de Desenvolvimento Científico e Tecnológico (CNPq, Projects 401769/2010-0 and 461628/20147) and Fundação de Amparo à Pesquisa do Estado de São Paulo (FAPESP, Project 2009/50876-4). Authors are members of the CNPq Research Productivity Fellowship Program (308844/2010-6 - PAS and 303523/2011-5 - JAJP).

\section{RESUMO}

A Formação Aquidauana é uma unidade sedimentar permocarbonífera, estratigraficamente bem distribuída nas porções norte e noroeste da Bacia do Paraná. Entretanto, poucos dados palinológicos são disponíveis para esta formação, limitando interpretações bioestratigráficas e paleoecológicas acuradas. Uma abundante, diversificada e bem preservada assembleia de palinomorfos foi registrada a partir de uma amostragem de uma seção aflorante realizada no Distrito de Cipolândia, cidade de Aquidauana, Estado do Mato Grosso do Sul, Brasil. Um total de 35 táxons de palinomorfos indígenas foi reconhecido, compreendendo seis espécies de esporos (relacionados a cinco gêneros), 28 espécies de grãos de pólen (14 gêneros) e 1 espécie de alga clorofícea. Grãos de pólen monossacados são excepcionalmente dominantes, representando 90,38\% da associação, particularmente constituídos por espécies dos gêneros Cannanoropollis (30.41\% do total da assembleia), Potonieisporites (28,14\%) e Plicatipollenites (19,52\%). Esta super representatividade quantitativa não é usual em depósitos do Gondwana, revelando uma dominância especial das Cordaitales no na flora terrestre. Estes resultados são interpretados como resultante de condições ecológicas caracterizadas por plantas que ocupavam terras altas, com independência de umidade na estratégia de reprodução, sob influência climática glacial. Certas espécies de grãos de pólen permitem posicionamento na Zona Crucisaccites monoletus (Pennsilvaniano tardio), a qual tem sido reconhecida somente na porção média do Grupo Itararé na margem nordeste da bacia.

Palavras-chave: bioestratigrafia, paleoecologia, palinologia, Pennsilvaniano.

\section{REFERENCES}

ARAI M AND MELO JHG. 2003. The occurrence of shear-torn palynmacerals in Middle to Early late Devonian strata of Southern Subandean Bolivia: their geological significance. In: Simposio Bolivariano - Exploración Petrolera en las Cuencas Subandinas, VIII, 2003. Cartagena, Bolivia. Memorias... Cartagena 1: 16-20.

AzCUY CL. 1979. A review of the early Gondwana palynology of Argentina and South America. In: International Palynological Conference, IV, 1976, Lucknow, India. Proceedings... Lucknow: 2: 175-185.

Backhouse J. 1991. Permian Palynostratigraphy of the Collie Basin, Western Australia. Rev Palaeobot Palynol 67: 237314.

BALME BE. 1980. Palynology and the Carboniferous-Permian boundary in Australia and other Gondwana continents. Palynology 4: 43-55.

BALME BE. 1995. Fossil in situ spores and pollen grains: an annotated catalogue. Rev Palaeobot Palynol 87: 81-323.

BAtTen DJ AND GRENFell HR. 1996. Chapter 7D. Botryococcus. In: Jansonius J and Mcgregor DC (Eds), Palynology: principles and applications. Amer Assoc Stratigr Palynol Found 1: 205-214.

BoARDMAN DR, SOUZA PA, IANNUZZI R AND MORI ALO. 2012. Paleobotany and palynology of the Rio Bonito Formation (Lower Permian, Paraná Basin, Brazil) at the Quitéria Outcrop. Ameghiniana 49(4): 451-472.

CAZZulo-Klepzig M, Menegat R AND Guerra-Sommer M. 2005. Palynology and palaeobotany in the reconstructon of the landscape units from the Candiota Coalfield, Permian of Paraná Basin, Brazil. Rev Bras Paleont 8(1): 83-98.

DAEMON RF AND QUAdRos LP. 1970. Bioestratigrafia do Neopaleozóico da Bacia do Paraná. In: Congresso Brasileiro De Geologia, XXIV, 1970, Brasília, Anais... SBG, Brasília, p. 359-412. 
Di PASQUO M, AZCuY CL AND SouZA PA. 2003. Palinología del Carbonífero Superior del Subgrupo Itararé en Itaporanga, Cuenca Paraná, Estado de São Paulo, Brasil. Parte 2: sistemática de pollen y significado paleoambiental y estratigráfico. Ameghiniana 40(3): 297-313.

FÉlix CM, Souza PA AND CANCELli RR. 2007. Diversidade de grãos de pólen monossacados da Bacia do Paraná: distribuição estratigráfica e implicações florísticas. In: Carvalho IS et al. (Eds), Paleontologia: Cenários da vida, Rio de Janeiro: Ed. Interciência, Rio de Janeiro, Brasil 7: 499-509.

FrANÇA AB AND POTTER PE. 1988. Estratigrafia, ambiente deposicional e análise de reservatório do Grupo Itararé (Permo-Carbonífero), Bacia do Paraná (parte 1). Bol Geoc Petrobras 2: 147-191.

Gandini R, Guimarães Netto R AND Souza PA. 2007. Paleoicnologia e a palinologia dos ritmitos do Grupo Itararé na pedreira de Águas Claras (Santa Catarina, Brasil). Gaea 3(2): 47-59.

Holz M, França AB, SOUZa PA, IANNuZzi R AND Rohn R. 2010. A stratigraphic chart of the Late Carboniferous/ Permian succession of the eastern border of the Paraná Basin, Brazil, South America. J South Am Earth Sci 29: 381-399.

Jones MJ AND TRUSWELl EM. 1992. Late Carboniferous and Early Permian palynostratigraphy of the Joe Joe Group, southern Galilee Basin, Queensland, and implications for Gondwanan stratigraphy. BMR J Austr Geol \& Geoph 13: 143-185.

LINDSTRÖM S. 1995. Early Permian palynostratigraphy of the northern Heimefrontfjella mountain-range, Dronning Maud Land, Antarctica. Rev Palaeobot Palynol 89: 359415 .

Milani EJ, Melo JHG, Souza PA, Fernandes LA and FrançA AB. 2007. Bacia do Paraná. Bol Geoc Petrobras 15(2): 265-287.

Mori ALO, SOUZA PA, MARQues JC AND Lopes RC. 2011. A new $\mathrm{U}-\mathrm{Pb}$ zircon age dating and palynological data from a Lower Permian section of the southernmost Paraná Basin, Brazil: biochronostratigraphical and geochronological implications for Gondwanan correlations. Gondwana Res 21: 654-669.

PLAYFORD G AND DINO R. 2000. Palynostratigraphy of upper Palaeozoic strata (Tapajós Group), Amazonas Basin, Brazil: Part two. Palaeontographica Abt B 255: 87-145.

Quadros LP AND Melo JHG. 1987. Método prático de preparação palinológica em sedimentos pré-mesozóicos. Bol Geoc Petrobras 1(2): 205-214.
SCHEFFler AS, MARTINS GR, KASHIMOTO EM AND DE OLIVEIRA GAM. 2010. Revisão sobre a paleontologia no estado do Mato Grosso do Sul: fósseis e afloramentos descritos. J Braz Geogr 1: 65-99.

SouZA PA. 2006. Late Carboniferous palynostratigraphy of the Itararé Subgroup, northeastern Paraná Basin, Brazil. Rev Palaeob Palyn 138: 9-19.

SouzA PA AND Marques-Toigo M. 2005. Progress on the palynostratigraphy of the Permian strata in Rio Grande do Sul State, Paraná Basin, Brazil. An Acad Bras Cienc 77(2): 353-365.

SOUZA PA, MORI ALO, PERINOTTO JAJ AND ARAúJo BC. 2013 Ocorrência de palinomorfos na Formação Aquidauana (Cipolândia, MS), Bacia do Paraná: significado bioestratigráfico e paleoecológico. In: Simpósio Brasileiro de Paleobotânica e Palinologia, XIV, 2013, Rio de Janeiro, Brasil. Anais... Rio de Janeiro: Série Livros 49, p. 172.

SOUZA PA AND PETRI S. 1998. Reworked palynomorphs in the Upper Carboniferous sediments at Araçoiaba da Serra (Itararé Subgroup, Paraná Basin), State of São Paulo, Brazil. Ameghiniana 35(4): 379-385.

SouzA PA, PETRI S AND Dino R. 2003. Late Carboniferous palynology from the Itararé Subgroup (Paraná Basin) at Araçoiaba da Serra, São Paulo State, Brazil. Palynology 27: 39-74.

SRIVASTAVA AK AND AGNiHOtri D. 2009. Palaeo-botanical perspective of Satpura Gondwana Basin, Madhya Pradesh. In: Kumar A et al. (Eds), Earth System Sciences, New Delhi: Concept Publishing Company, New Delhi, India 1: 585-595.

STEPHENSON MH. 2008. A review of the palynostratigraphy of Gondwanan Late Carboniferous to Early Permian glacigene successions. The Geol Soc Am, Special Paper 441, p. 317-330.

STEPhenSON MH ANd OSTERLOFF PL. 2002. Palynology of the deglaciation sequence represented by the Lower Permian Rahab and Lower Gharif Members, Oman. AASP Contr. Series 40, p. 1-41.

TIWARI RS AND TRIPATHI A. 1992. Marker assemblage zones of spores and pollen species through the Gondwana Palaeozoic and Mesozoic sequence in India. Palaeobotanist 40: 194-236.

VENKATACHALA BS, TIWARI RS AND ViJAYA. 1995 Diversification of spore-pollen "character states" in the Indian Permian. Rev Palaeob Palyn 85: 319-340.

Wagner R. 2001. Fósiles vegetales. Córdoba, Diputación de Córdoba, Recursos Naturales de Córdoba 6: 105. 